\title{
異種材料界面の諸特性評価システム「サイカス」 Characteristic Evaluation for Interface of Different Materials by SAICAS System
}

\section{1.はじめに}

異種材料からなる複合材料には必ず表面・界面が存在 する。各構成材料の単独での特性評価以外に, 例えばコー ティング材の厚みによる特性の差, 表面・界面を制御す る処理条件の違いによる性能差, 各材料間の接着あるい は付着強さ・その剥離状況, 剥離面の光学的・化学的な 観察, これらの評価項目及び解明方法の選択・結果が研 究開発, 生産者にとり重要であり, 更なる進歩に慗がる。

一般に, 異種材料の界面近傍の評価項目はいろいろあ るが, 代表的なのが, 接着あるいは付着性能の評価であ ろう。各材料間の付着・剥離強さの評価方法として, ピー ル剥離, せん断剥離, プルオフ試験, クロスカット試験, 碁盤目テープ剥離などが行われている。しかしこれらは, サンプルの前処理に時間がかかること, 大面積のサンプ ルが必要なこと, 試験方法によっては数值化が難しいこ と, 碁盤目テープ剥離では, 付着しない材料や, 凹凸の あるものは難しいこと, 接着材が使えないものは付着強 度の評価は不可能などの課題を抱えている。また, 室温 以外に低温や高温状態での評価も必要なこともあり，簡 単な方法では難しい問題むある。さらには, 厚みが 1 ミ クロンより薄いものや硬くて脆いものなど評価できない ことが多い。

ここに紹介する「サイカス」システム1,2)は，特別な

\footnotetext{
*ダイブラ・ウィンテス(胡代表取締役社長 さいたま市大宮区上小町 202 トマキビル $2 \mathrm{~F}$ テ $330-0855$ Daipla Wintes Co., Ltd.

2F Tomaki Bldg. 202 Kamiko-cho, Omiya-ku, Saitamashi, SAITAMA 303-0855, Japan

**ダイプラ・ウィンテス(椒サイカス営業本部部長

兵庫県三田市西野上 367 个 $669-1314$

Daipla Wintes Co., Ltd.

367 Nishinogami Sanda-shi, Hyogo 669-1314, Japan
}

\author{
木嶋 芳雄 $^{*}$. 西山 逸雄 ${ }^{* *}$
}

Yoshio KISHIMA and Itsuo NISHIYAMA

鵨験片に加工する必要がなく，温度対応す簡便で，しか あ微少量・面積で材料の諸特性（せん断強度や剥離強さ） を特定できる評㑛システムである。

\section{2.「サイカス」とは？}

「サイカス」とは, Surface And Interfacial Cutting Analysis System の 頭文字を経った造語である。「サ イカス」の測定原理を図1に示したが，その原理はプラ スチックの 2 次加工である切削を応用したあので, 表面 から内面, さらには異種材料であれば界面近傍まで連続 的に切込み, その時の水平・垂直の切削力と刃先の試料 表面からの位置をコンピュータに取り込み, グラフ化或 いは数値化して解析ソフトにより材料の諸物性を評価解

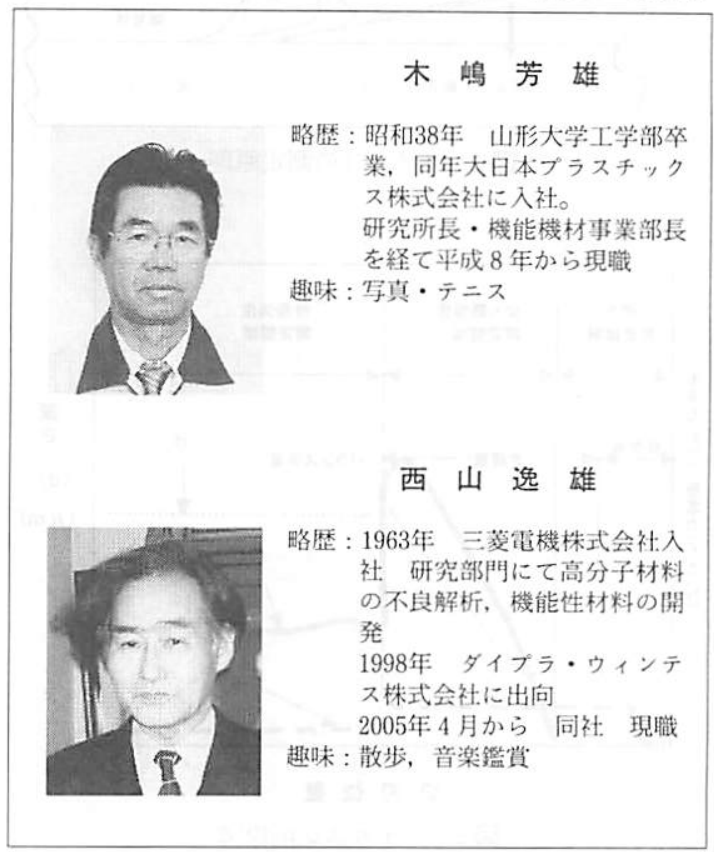


析するシステムである。測定サンプルは平板状で切刃が 切込むことを要件とする。

\section{1 測定原理・切削線図}

材料の構造によりいろいろな切削線図が得られるか， 単純な二層からなる材料を表層から切削した場合の模式 図「サイカス切削線図」を図 2 に示した。

図 1 及び 2 により説明すると，まず，切为をサンプル 表面に合わせる。次に所定の押し圧荷重を加える。切刃 は，サンプル内に押し込まれるので，その深さから硬さ を求めることができる。次に, 切刃の運動を開始すると, 切羽は試料内に切り込む。これが切込み段階であり，一 定荷重に保ちながら, 深くなるにつれて水平力 $\left(\mathrm{F}_{\mathrm{H}}\right)$, 垂直力 $\left(\mathrm{F}_{\mathrm{v}}\right)$ が上昇する。この領域で, せ九断強度の深 さ方向での解析を行なう。材料の性質の暹いや構成材料 の種類によって切削力 $\left(\mathrm{F}_{\mathrm{H}}, \mathrm{F}_{\mathrm{V}}\right)$ に違いが生じる。次に 界面近傍に達すると最弱層付近で龟裂が発生し $F_{H}, F_{V}$ が低下する。

切刃が界面近傍に到達した時点で切刃の動きを水平方 向のみとするため, 垂淔運動を停止するかバランス荷重 を調整して位置制御を行ない, 水平運動を継続して行な

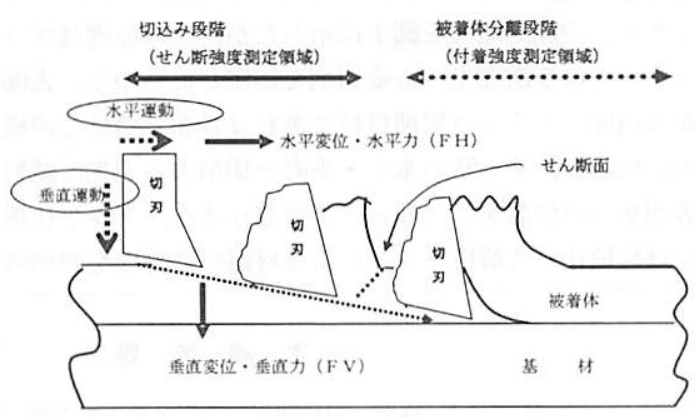

図 1 サイカスの測定原理

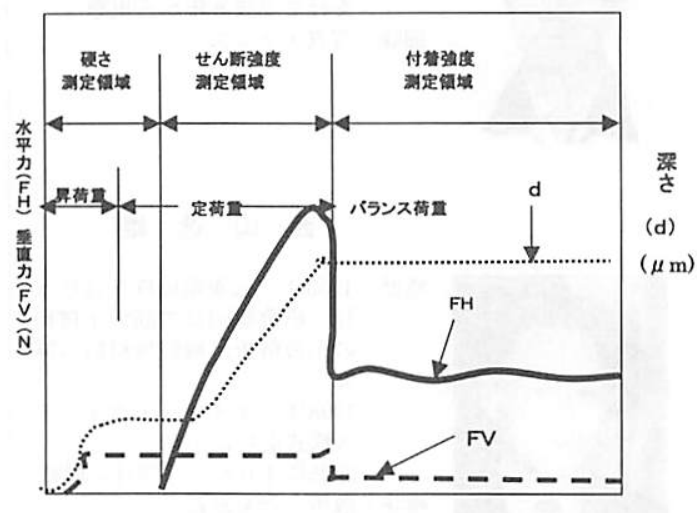

切刃位 霊

図 2 サイカス切削線図
うことによって被着体を基材から分離する。

最初の切込み段階で材料のせん断強度の計算や, 切削 パターンの比較から機械的特性などの違いを判断する。 また，被着体分離段階で付着性の評価が可能となる。

\section{2 切刃先端のベクトル図}

マーチャントの切削理論 ${ }^{3)}$ では, 材料中の一定深さを 連続切削することによりせん断強度を求めるが, この切 削状態における切刃の先端のベクトルを図 3 に示す。図 中切刃すくい面の垂直押し圧荷重 $(\mathrm{N})$ とすくい面の摩 擦力 $(T)$ から合力 $(R)$ が求まる。各種記号の内容を次 に示す。

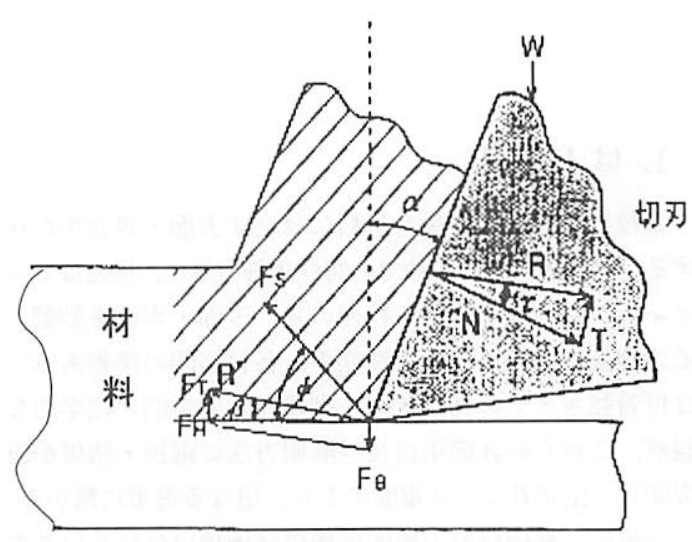

図 3 切刃先端ベクトル

$\mathrm{R}^{\prime}: \mathrm{R}$ と反対の力, $\tau$ : 摩擦角, $\alpha$ : すくい角, $\beta: \mathrm{R}^{\prime}$ 之 水平となす角, $\phi$ : せ九断角, $\mathrm{F}_{\mathrm{S}}$ : せ九断力, $\mathrm{F}_{\mathrm{C}}$; 切削 力, $\mathrm{F}_{\mathrm{T}}$ : 推力, $\mathrm{W}$ : 押圧荷重, $\mathrm{F}_{\mathrm{B}}$ : バランス荷重である。 この場合, 切刃先端には上向きの推力 $\mathrm{F}_{\mathrm{T}}$ が生じてお り，この力と同等の荷重 $\mathrm{F}_{\mathrm{B}}$ を加えるとベクトルの合力 は水平方向となり，所定の深さでバランスを保つことが 可能となる。

\section{3 サイカスにおけるデータ解析方法}

2.3.1 みなしせん断強度の計算式及び求め方

サイカスにおけるせん断強度 $(\tau)$ の計算式は, 次式 による。

$$
\tau=\mathrm{F}_{\mathrm{H}}^{*} / 2 \mathrm{~A}_{0} \cdot \cot \phi(\mathrm{Pa})
$$

ここで, $\mathrm{A}_{0}$ : 断面積 $(\mathrm{d} \times \mathrm{W}), \mathrm{F}_{\mathrm{H}}^{*}: \mathrm{F}_{\mathrm{H}}-\mathrm{d}$ 関係から求 めた值。

せん断強度は, 切刃が材料中を切り込むときのデータ から求めるが,この場合, 材料はせん断破壊を繰り返す ことを前提とする。得られるデータにはせん断力以外に (1)切刃稜丸みによる抵抗力, (2) 押し圧荷重による抵抗 が含まれているので，これらの力を除去する必要がある。 そのために次の処理をおこなう。 


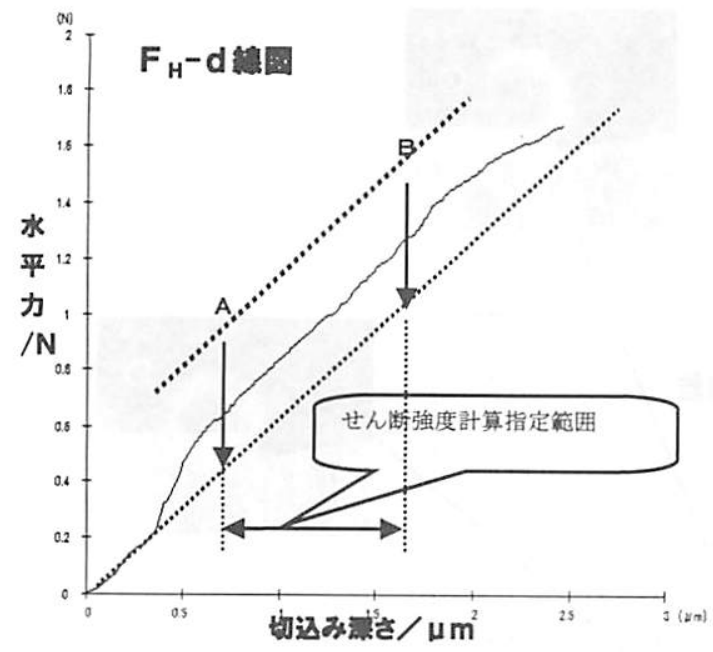

図 $4 \quad \mathrm{~F}_{\mathrm{H}}-\mathrm{d}$ 関係図

イ ; 界面一表面切削データを, 深さと切削力 $\left(\mathrm{F}_{\mathrm{H}}-\mathrm{d}\right)$ の関係図（図 4）に变換する。四において，指定する範 囲のデータを最小二乗法によって処理した直線を得る。 その直線には上述の 2 種類の力が含まれる。 ロ：この (1) + (2)) を除くために, $\mathrm{F}_{\mathrm{H}}-\mathrm{d}$ 関係闵の直線 部の勾配で原点を通る直線に变換する。このグラフの值 からせん断強度を求める。せん断強度は, 均質な材料で あれば深さによらず一定である。実際には，架橋度や異 方性あるいは内部ひずみ等が混在するために一定よはな りにくい。

せん断角は実際に測定するのが望ましいが, 簡便に 45 度とし，そのためにみなしせん断強度とした。

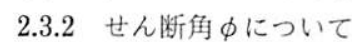

切削理論に基づくせん断角は切削条件や材料の諸性質 によって変化することが予想されるが，この測定法では， 概略的に $\phi=45$ 又は任意の值を代入して, せん断強度 を求めている。より正確な值を必要とする場合は, 所定 の深さで連続的にせん断破壊を起こさせ，その時のバラ ンス荷重の値から (2) 式を用いてせん断角を求める方法 がある。

$$
\phi=45+\tan ^{-1}\left(\mathrm{~F}_{\mathrm{T}} / \mathrm{F}_{\mathrm{H}}\right) / 2
$$

実際硬質透明 PVCにてせん断角を測定した例を示す。 せん断角は約 30 度であった。

2.3.3 剥離強度の計算式及び求め方 サイカスでの剥離強度 (P) は, 次式による。

$$
\mathrm{P}=\mathrm{F}_{\mathrm{H}} / \mathrm{W}(\mathrm{N} / \mathrm{m})
$$

$\mathrm{F}_{\mathrm{H}}$ : 剥離状態での水平力, $\mathrm{W}$ : 切刃の幅

切刃を押し圧荷重の調節により界面近傍でバランスさせ

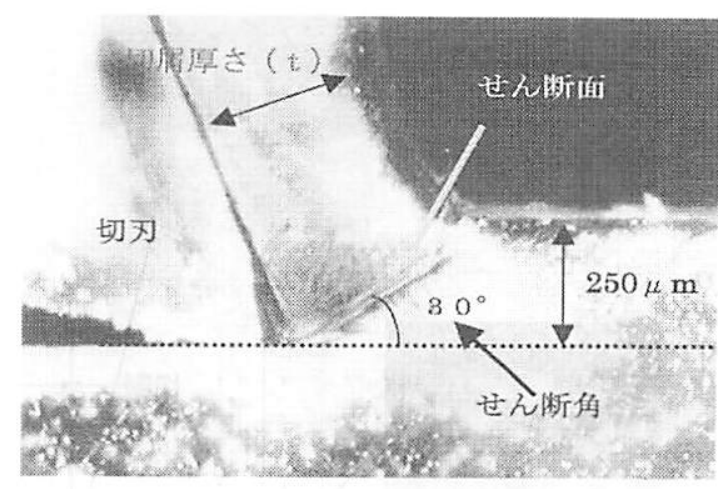

写真 1 PVC の光弾性稿写真

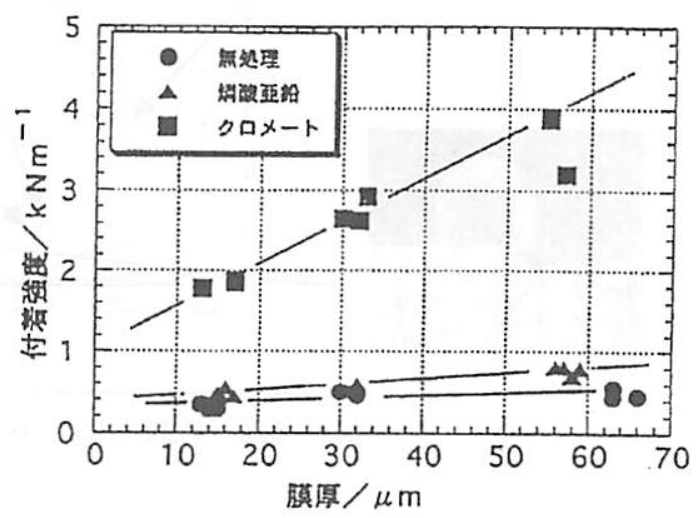

図 5 メラミンアルキッド鉒膜の付着強度

るか，または，その時点で先の降下運動を停止させる。 このときの切刃と基材面との摩擦力は含まれないと仮定 し, 範井指定したポジションでの水平力を求め $\left(\mathrm{F}_{\mathrm{H}}\right)$, その值を切內の幅で除して，この值を剥離強度としてい る。この值を, ピール強度との違いを説明すると, 切刃 のすくい面にて切削片を前方に押し付ける力を平均化し ているが,この中には, 切片の剛性や切刃との摩擦力, 切刃サイドの引き裂き力など含まれている。

メラミンアルキッド型焼付け塗膜に関して, 膜厚と鋼 鈑の表面処理の違いによる付着強度を評価したデータ （図 5）から, 同じ塗膜でも膜厚の違いにより剥離強さ が変化し，膜厚が厚くなるほど付着力が大きくなる傾向 を示した ${ }^{4,5)}$ 。

\section{4 切削線図と剥離状態の関係観察写真}

次に，実際にサイカスにより，界面近傍を評価した場 合の切削線図とそのデータの各位置での切削状態の写真 と比較しながら現象を解説する。

2.4.1 焼付け多層膜の切削・剥離（非定常型剥離）

A. 表層を切削。ここでは，深くなるにつれて水平方向 と垂直方向の力が上昇する。 


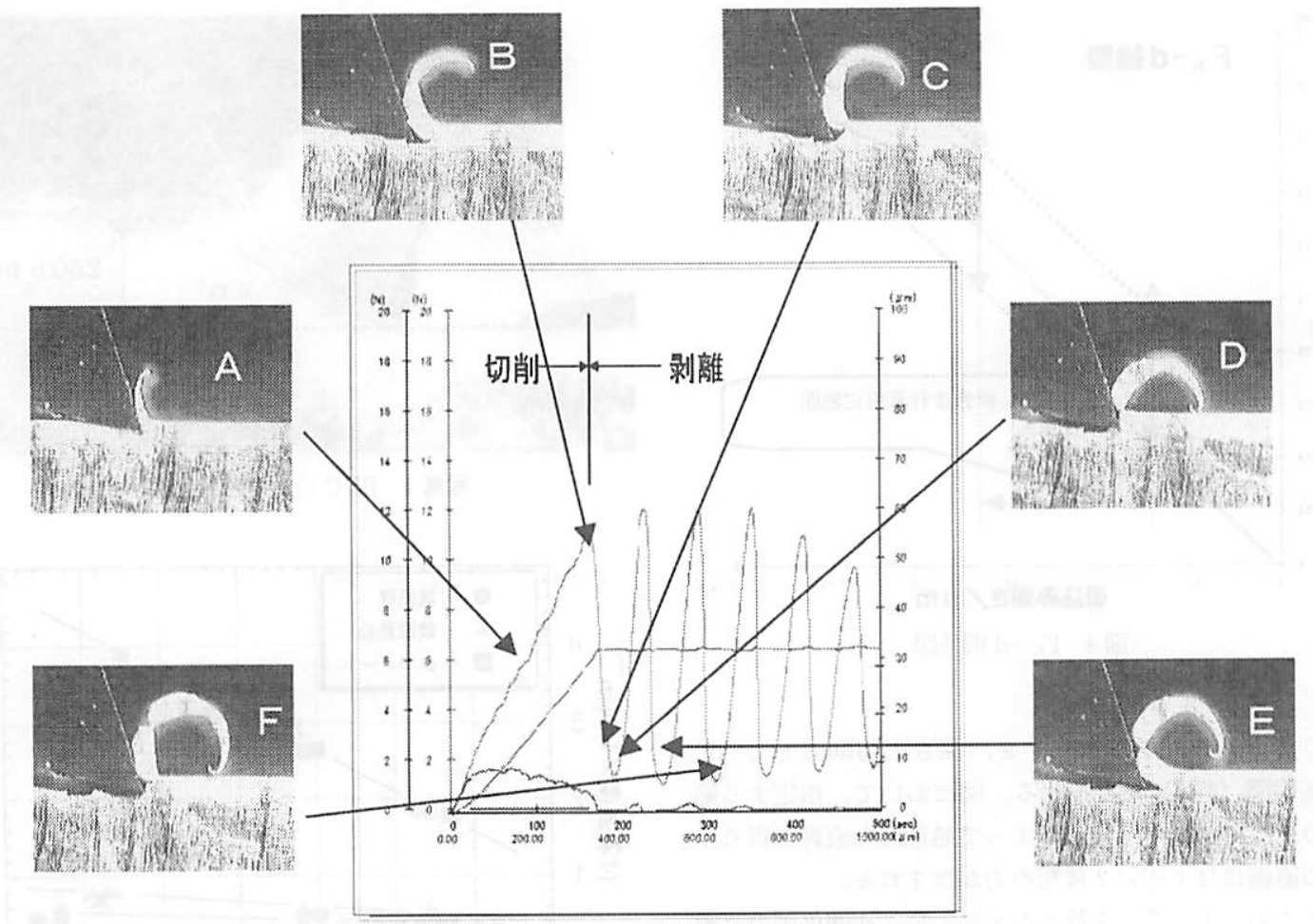

図 6 多層膜の界面近傍の破壊状況観察例と切削線図

B. 一層目の剥離が開始。鬼裂の進行に伴って水平方向 の力の低下が起こる。

C. その後さらに切り込むが, 刃先の先端に龟裂が拡大 したために水平・垂直方向の力がさらに低下する。 刃先の先端に材料が接触していない状態。ここで, 刃物の垂直への運動を停止する。それにより二層目 と下地の界面の剥離強さを測定する。

D. 二層目の残塗膜に刃先が触れ，切り込むために水平方 向の力が上昇する。同様に B からの状態を繰り返す。

$\mathrm{E}, \mathrm{F}$. 塗膜が基材に残存しているパターン（非定常型剥 離) となる。

湮膜の剥離面の写真 2 を示した。

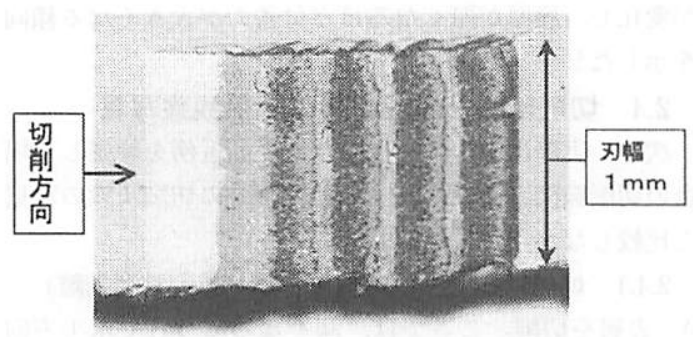

写真 2 切削・剥離面写真
基材面に塗膜が残存し波を打ったような破壊の繰り返 しが簣える。

2.4.2 磁気カードの磁気層の剥離（定常型剥離）

次に，界面近傍を連続的に剥噰している切削パターン (定常型剥離) を示す。

これは，磁気カードの磁父層付近（約 25 ミクロン） を切削した例（図7）である。

写真 3 に見られるように, 切刃の前方に切片が一定の 形状で連続的に形成される。

切削面の钼察写真 4 を右に示した。

写真 2 之違って, 切削跡には切削片が残っていないの が窥える。

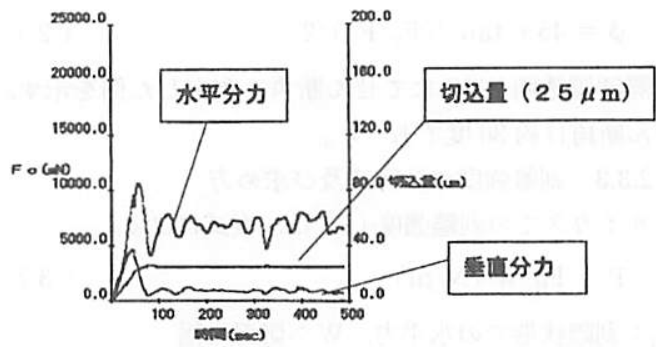

図 7 磁父九ードの測定 


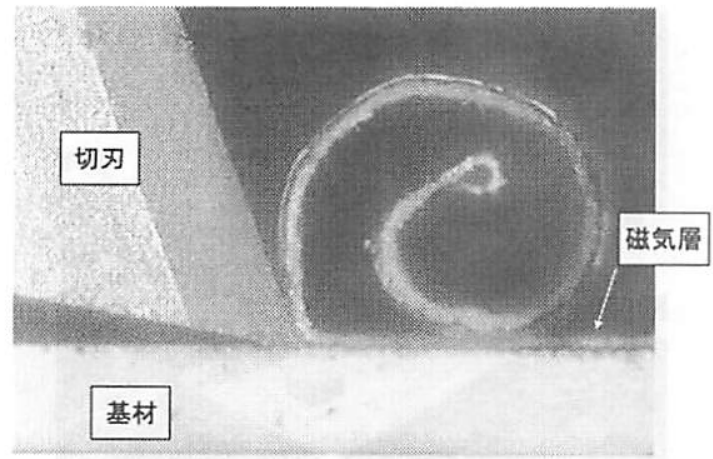

写真 3 磁気層剥離

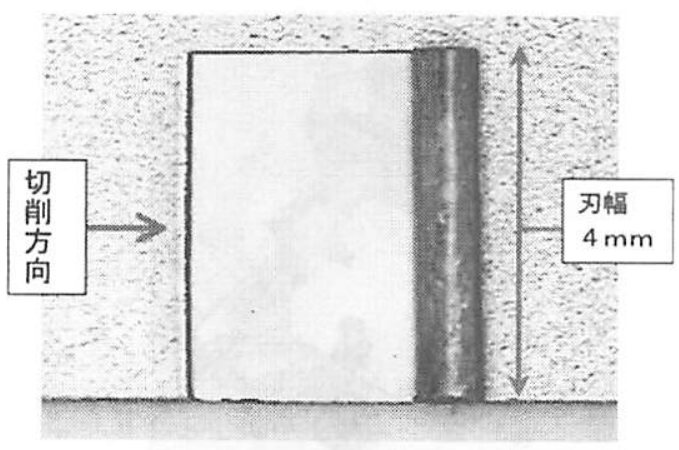

写真 4 切削面観察

2.4.3切削時温度を变えた場合の切削線図と剥離の 関係

サイカスは，切削時の温度をマイナス $140^{\circ} \mathrm{C}$ かプラ ス $250^{\circ} \mathrm{C}$ まで対応が可能である。これは, 温度コントロー ルした $\mathrm{N}_{2}$ ガスを微小面積に吹き付ける方式である。吹 き付け装置を写真 5 に示した。

焼付け型多原膜の切削で, 温度を变えた場合の破壊状 態の観察例を写真 6 に示す。また同時に得られる切削線 図を図 8 に示した。

左が $20^{\circ} \mathrm{C}$, 右がマイナス $65^{\circ} \mathrm{C}$ で, 両者の比較で同じ

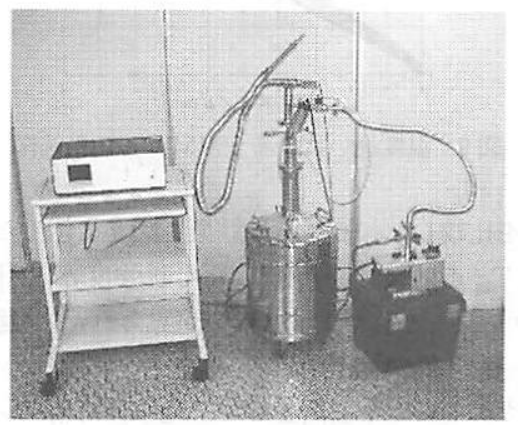

写真 5 吹付け装置
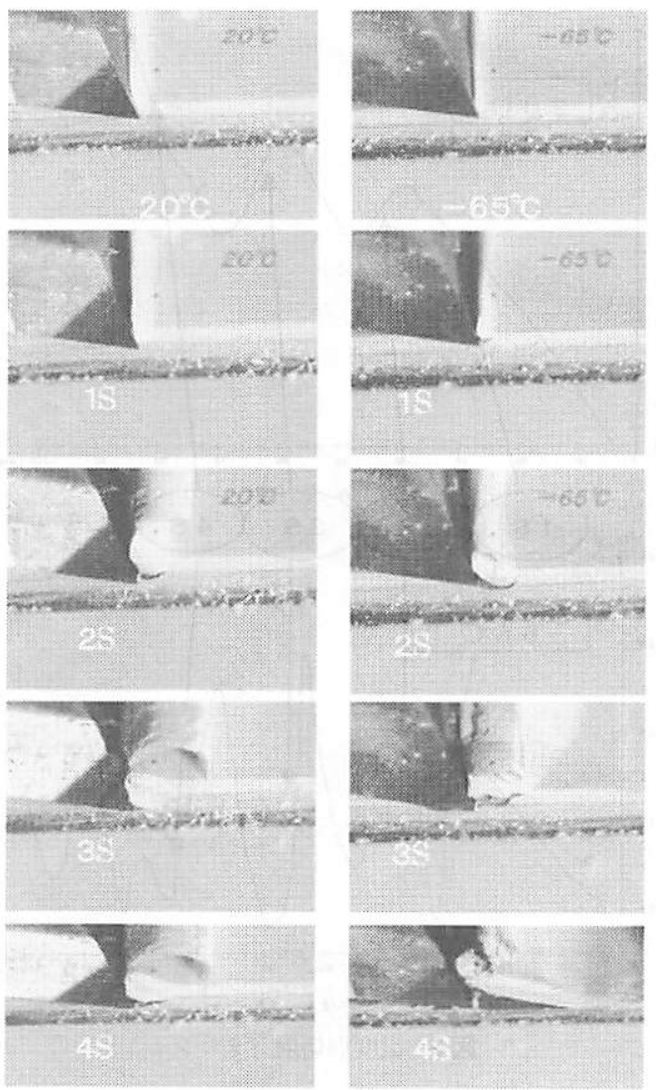

写真 6 温度違いによる多層膜の破壊

$1 \mathrm{~S} ;-65^{\circ} \mathrm{C}$, 切刃先端に龟裂が入る

$2 \mathrm{~S}, 3 \mathrm{~S}$; 雨者に龟裂が入るが， $-65^{\circ} \mathrm{C}$ の方が大きい。 $4 \mathrm{~S} ;-65^{\circ} \mathrm{C}$ の方が大きく剥離している。[破壊している]

切削深さでの绪裂の発生開始の違いが図 8 に見られるよ うに，切削パターンにも明確に現れている。このように 淘膜の種類によっては低温になるに従って, 脆性化によ り破壊しやすいことが窥える。

\section{3. サイカスの機種}

「サイカス」の型式は, $1 \mu \mathrm{m}$ から $1000 \mu \mathrm{m}$ 程度まで の従来の塗膜・複合材などの評価用から，50ナノメ一 夕から $5 \mu \mathrm{m}$ 以下の薄膜評価用之 2 種類に分かれてい る。

写真 7 に, 厚膜対応型 : モデル DN-20 型, 写真 8 に 薄膜対応型：モデル NN-03 型の切削部の概钼, 各型式 の動作可能範囲を表 1 に示した。

薄膜対応の NN-03 型の心臟部は, 切削機構にある。 駆動部は, 遊びがない圧電素子機構を使用し, 超微速度 で刃物を動かす機構となっている。駆動機構の遊びがな いために, 垂直变位の分解能が 5 ナノメーターと格段に 向上した。 


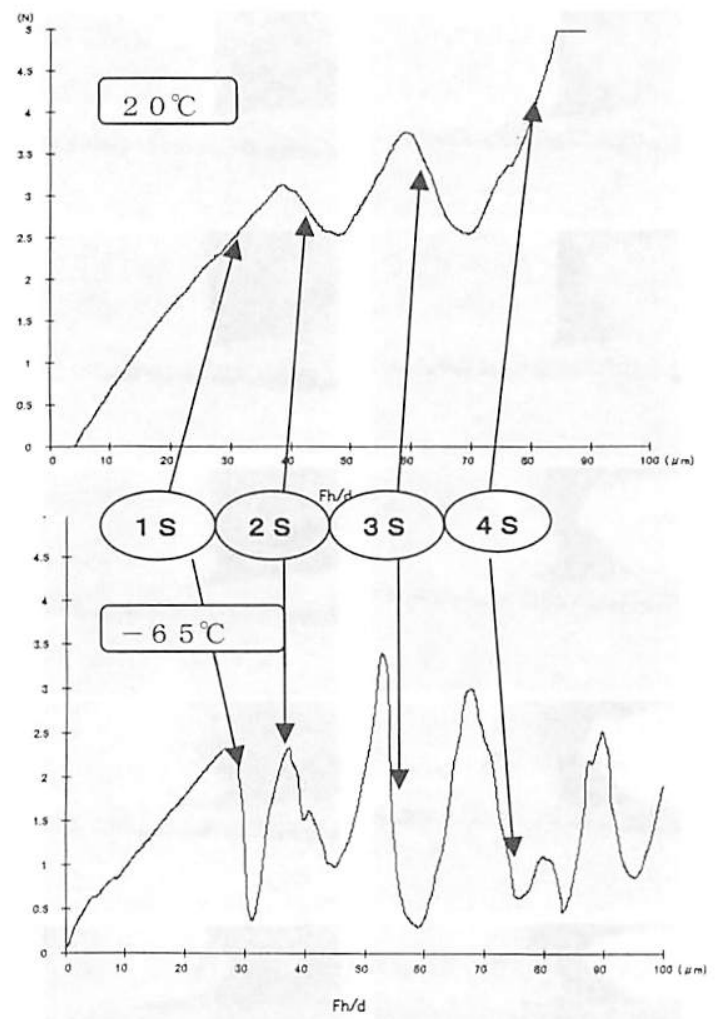

図 8 温度別切削パターン

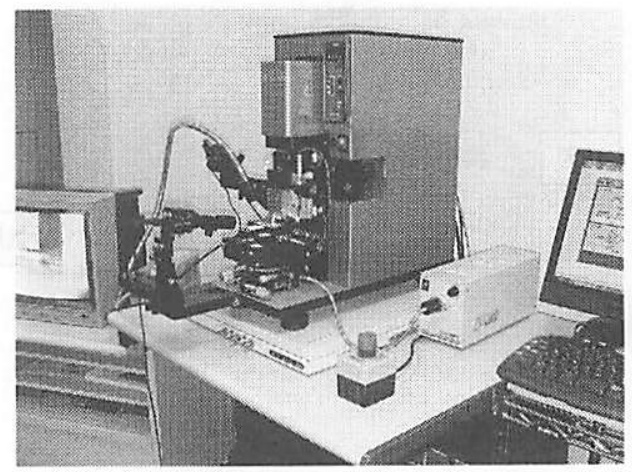

写真 7 サイカス $\mathrm{DN}-20$ 型

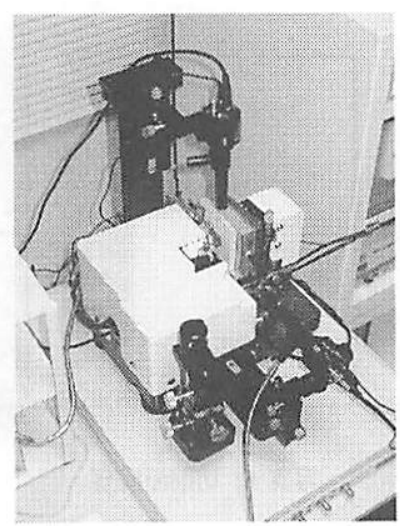

写真 8 サイカス $N N-03$ 型 切削部

表 1 サイカスの型式と動作可能範囲

\begin{tabular}{c|c|c|c|c}
\hline 型 式 & $\begin{array}{c}\text { 垂直 速度 } \\
(/ \text { 秒 })\end{array}$ & $\begin{array}{c}\text { 水平 } \\
(/ \text { 秒 })\end{array}$ & $\begin{array}{c}\text { 垂直・水平 } \\
\text { 検出荷重 }(\mathrm{N})\end{array}$ & 垂直 変位 \\
\hline $\mathrm{DN}-20$ & $0.002 \sim 5 \mu \mathrm{m}$ & $0.02 \sim 50 \mu \mathrm{m}$ & $0.1 \sim 20$ & $0.1 \sim 1000 \mu \mathrm{m}$ \\
\hline $\mathrm{NN}-03$ & $1 \sim 500 \mathrm{~nm}$ & $1 \sim 500 \mathrm{~nm}$ & $0.001 \sim 3$ & $5 \mathrm{~nm} \sim 5 \mu \mathrm{m}$ \\
\hline
\end{tabular}

測定時の水平速度は DN 型で $0.02 \sim 50 \mu \mathrm{m} /$ 秒の速 さで, $\mathrm{NN}$ 型では, $1 \mathrm{~nm} /$ 秒以上で行われる。これは, 切削時の熱の影響を避け, 切削の安定性のため極低速度 で切削で行われる。使用バイトは単結晶ダイヤモンド, ボラソン合金製を使用し，刐幅 $0.3 \mathrm{~mm}$ から $4 \mathrm{~mm}$ まで 対応が可能で, 測定試料必要面積は $10 \times 10 \mathrm{~mm}$ 程度以 上で微小面積である。

\section{4. 各種材料での測定例}

実際の材料について表面から内面に切り込む過程のデー 夕により，どのような情報が得られるかを紹介する。

\section{1 熱可塑性プラスチックの温度变化による 切削線図 $\left(\mathrm{F}_{\mathrm{H}} \text { パターン }\right)^{6)}$}

高分子材料の諸性質は温度によって変化するが，アク リル樹脂 $\left(\mathrm{Tg}: 3{ }^{\circ} \mathrm{C}\right)$ について温度の違いによる切削パ

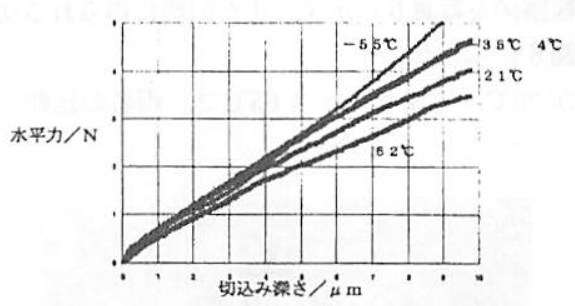

図 9 温度違いによる PMMA の切削線図

ターンを比較した。それらの結果を図 9 に示した。この 樹脂の $\mathrm{Tg}$ 点前後でのみなしせん断強度と, 引張強度 （カタログ值）と似たような傾向が見られた。（図 10）

\section{2 長距離斜め切削}

サイカスの新たな展開として，化学分析用サンプルの 前処理用として, 評価する膜の表面から内面へ長距離斜 


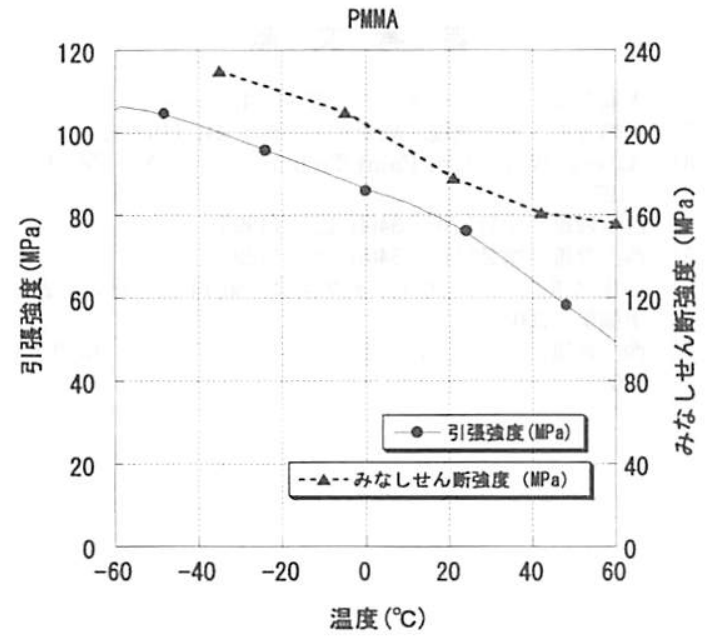

図10 みなしせん断強度と引張強度の温度特性

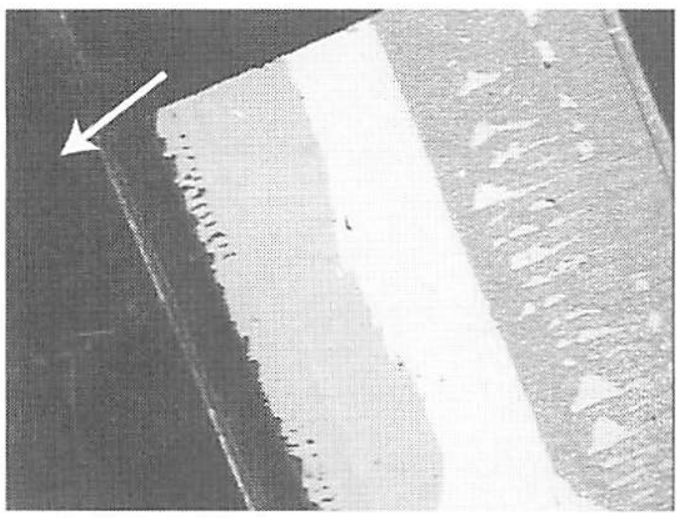

写真 94 層渉膜の斜め切削例

（切削方向；白矢印 黒一ねずみ一白一赤系塗膜）

めに切削し, その面を, 顕微 IR, EPMA, TOF-SIMS 等で分析することにより, 分子結合状態, 元素の深さ方 向解析等に使用できる。この場合, 電子線での掘り下げ と異なり分子結合のダメージがない特徴を有する。写真 9 に「4 層塗膜の斜め切削例」を示したか，こ上うに各 層を露出し, 観察や内容物の分布, 化学分析などが可能 である。

\section{3 ポリカーボネート樹脂の表層劣化分析例 ${ }^{7}$}

サイカスによる表層の深さ方向の分子權造を評価した 例を紹介する。試験前之耐候性試験を行った試料につい て, 反射顕微赤外分光分析器を用いて樑さ方向の組成の 变化を追跡した。そのデータを図 11〜12に示した。

暴露により茶褐色に変色するが, この生成物は, $1600 \mathrm{~cm}^{-1}$ に吸収を有しており $\mathrm{PC}$ 樹脂のビスフェノー ル型構造がベンソフェノン型構造に变化した結果である と推定された。酸化にとむなってカルボン酸が生成した

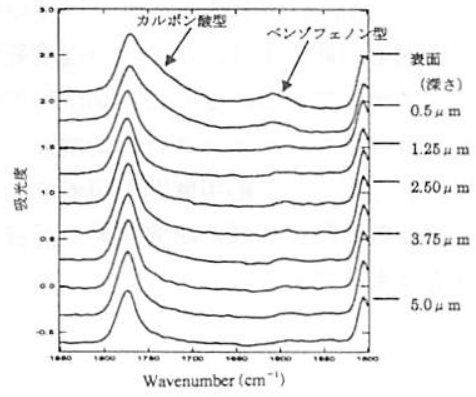

図11 表面加肉部への IR 分析

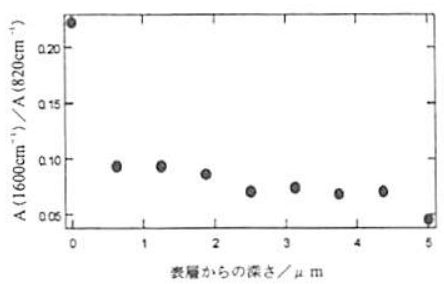

図 $121600 \mathrm{~cm}^{-1}$ (ベンソフェノン型構造）深さ方向の 吸収強度

ものと思われ，その生成物の深さは，1 $\mu \mathrm{m}$ 以内の極表 層に存在することが明らかになった。

\section{4 薄膜（800nm Low-k 膜）の評価例}

表面平滑化工程で CMP (Chemical Mechanical Polishing）があるが, 研磨によるせん断力で膜剥離の問題 がある。研磨条件や場所による差を無くすためにこのよ うな剥雄デー夕を蓄積し, 品質を安定させることが可能 となる。測定データの一例を図 13 に示した。

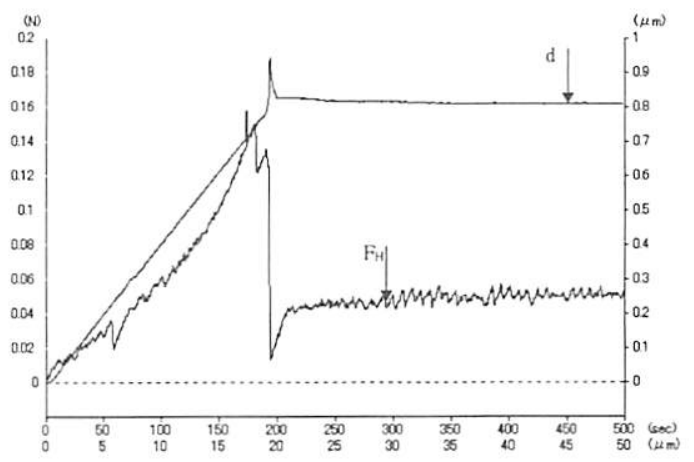

図 13 Low $-k$ 膜の测定データ

\section{5. おわりに}

サイカスは，表面から内面あるいは界面へと連続的に 切り込むことによりその深さと切削力の関係からいろい ろな現象を解析できることを紹介した。特に切削時の動 画と併用することにより，破壊面の推定が容易になった。 
0.5 ミクロンの薄膜から 100 ミクロン程度の厚膜まで 広範囲に評価対応可能であり,なおかつ温度範囲む広く 対応できるシステムである。さらに，切削時の熱的影蠁 がないために有機系コーティング材の切削面の化学構造 などの観察・評価用として応用展開も可能である。

これらの評価機器類が㫮様の研究開発や品質管理なよ゙ のお役に立てば幸いである。

\section{参 考 文 献}

1）木鸠芳雄，コンパーテック，22(9) 54，(1994).

2）木鸠劳雄，西山逸雄，成形加工，6(1) 41，(1994）.

3) Asbeck. W. K, J. of Paint Technology, 43, No. 556 (1971 -1975)

4）西山逸婎，壁装技術，34(4) 123，(1995）.

5）西山逸雄，塗装技術，34(5) 129，(1995).

6）西山逸雄, マテリアルライフ学会 第 14 回 研究発表会 予稿集 (2003).

7）西山逸雄，永井直人，マテリアルライフ学会誌，15(2) 66 , (2003). 